\title{
A Case of Struma Ovarii Diagnosed by Cytology during Laparoscopic Surgery
}

\author{
Kenji Niwa ${ }^{1}$, Motoki Takenaka ${ }^{2}$, Tsuneo Ishihara1, Sakae Mori ${ }^{3}$, Keigo Kuwabara ${ }^{3}$, \\ Saki Murase ${ }^{2}$, Yoshio Yamaguchi ${ }^{3}$, Takuji Tanaka ${ }^{4}$ \\ ${ }^{1}$ Department of Obstetrics \& Gynecology, Gujo City Hospital, Gujo City, Japan \\ ${ }^{2}$ Department of Obstetrics \& Gynecology, Gifu University School of Medicine, Gifu City, Japan \\ ${ }^{3}$ Section of Laboratory Medicine, Gujo City Hospital, Gujo City, Japan \\ ${ }^{4}$ Department of Diagnostic Pathology \& Research Center of Diagnostic Pathology, Gifu Municipal Hospital, Gifu City, Japan \\ Email: *kniwa.gujo913@gmail.com
}

How to cite this paper: Niwa, K., Takenaka, M., Ishihara, T., Mori, S., Kuwabara, K., Murase, S., Yamaguchi, Y. and Tanaka, T. (2019) A Case of Struma Ovarii Diagnosed by Cytology during Laparoscopic Surgery. Open Journal of Pathology, 9, 1-9.

https://doi.org/10.4236/ojpathology.2019.91001

Received: October 16, 2018

Accepted: December 14, 2018

Published: December 17, 2018

Copyright $\odot 2019$ by authors and Scientific Research Publishing Inc. This work is licensed under the Creative Commons Attribution International License (CC BY 4.0).

http://creativecommons.org/licenses/by/4.0/

\begin{abstract}
We report a case of pure struma ovarii tumor diagnosed by cytology during laparoscopic surgery. The patient was a 34-year-old Japanese woman, gravida 1 , para 1, who had the left adnexal mass, and was pre-operatively diagnosed as left ovarian endometriotic cyst or mature cystic teratoma by magnetic resonance imaging findings. She underwent laparoscopy, and the content of the left ovarian cystic tumor was found to be yellow gelatinous material, suggesting mature cystic teratoma. The imprint cytology of the tumor showed benign glandular pattern, suggesting struma ovarii. Histopathological findings led us to the diagnosis of pure struma ovarii with positive reactions for thyroglobulin and thyroid transcription factor- 1 . No metastases or disseminated lesions were detected. The patient has no recurrent signs 7 months after the operation.
\end{abstract}

\section{Keywords}

Struma Ovarii, Cytology, Immunocytochemistry, Immunohistochemistry, Thyroglobulin, Thyroid Transcription Factor-1

\section{Introduction}

Struma ovarii is a rare type of ovarian tumor that has been reported to represent $0.5 \%-1.0 \%$ of all ovarian tumors [1] [2] [3]. This tumor is the most common type of monodermal teratoma and comprises approximate $3.0 \%$ of all ovarian teratomas [1] [2] [4] [5]. It is defined as histologically characterized by the presence of thyroid-like glands at least 50\%. Malignant transformation of the struma 
ovarii, which is associated with $B R A F$ mutations and $R E T / P T C$ rearrangements [6] [7], as seen in papillary thyroid carcinoma of the eutopic thyroid, rarely occurs and its rate is reported to vary, ranging from $5 \%-10 \%$ [8]. Struma ovarii is predominantly found in women between the ages of 40 and 60 years [9]. While magnetic resonance imaging (MRI) analysis has been reported to be useful for the differential diagnosis [10] [11] [12], the preoperative differential diagnosis between the struma ovarii and other malignant tumor is difficult due to the morphological similarities. In fact, only a few reports concerning cytological diagnosis of struma ovarii have been reported [13] [14], although immunocytochemistry might be a valuable tool for accurate diagnosis of the struma ovarii [14]. We present here a rare case of struma ovarii in a 34-year-old woman, and the imprint cytology during the laparoscopic surgery was useful for the diagnosis of the neoplasm. Immunocytochemical and immunohistochemical examinations of thyroglobulin were useful to confirm the above diagnosis.

\section{Case Report}

A 34-year-old Japanese woman, gravida 1 para 1 with normal menstruation cycle, was referred to the Department of Obstetrics \& Gynecology, Gujo City Hospital, because of the left adnexal mass and secondary infertility introduced from a fertility clinic. Her sociodemographic and clinical characteristic of the patient was summarized in Table 1. Her medical history included her left ovarian cystectomy under a laparoscope at 32-year-old in other hospital in other prefecture. However, the patient and her family did not know the detailed information. Other diseases including thyroid tumor were not reported. Hyperthyroidism could not be detected. Magnetic resonance imaging (MRI) in our hospital revealed the left ovarian tumor containing cystic and solid parts, measuring $6.8 \times 5.2 \times 7.0 \mathrm{~cm}$. The cystic part showed variable signal intensity on the T2-weighed MRI scan (Figure 1(A)) and slightly high on T1-weighted (Figure $1(B)$ ), suggesting the content being bleeding or gelatinous (highly viscous) and colloidal material. MRI examination did not detect enlarged lymph nodes, ascites and disseminated lesions in the peritoneum. Pelvic ultrasonography (USG) showed right polycystic ovary (Figure 2(A)) and left ovarian cystic tumor with papillary protrusions (Figure 2(B)) before operation. Clinical laboratory data, including tumor markers (CA125, 7.2 U/ml; CA19-9, 8.6 U/ml) showed within normal limitations. Based on the above findings, our working diagnosis was left ovarian endometriotic cyst or mature cystic teratoma.

Under the working diagnosis, the patient underwent laparoscopy one month after her first visit. She received laparoscopic left oophorectomy (Figure 3) and the tumor dropped into the $\mathrm{ENDOPUCH}^{\oplus}$ (Ethicon, TX) without rupture. Her right ovarian drilling was also performed for trigger ovulation in this patient with polycystic ovary syndrome, suggested by the pelvic USG before surgery (Figure 2(A)). Electrocautery or a laser is used to destroy parts of the ovaries. The content of the cystic tumor was yellowish gelatinous fluid with approximate 
$150 \mathrm{ml}$, suggesting a mature cystic teratoma. There was no peritoneal fluid (ascites). On the imprint cytology of the tumor, the tumor cells showed glandular pattern. The tumor was thus suggested to be struma ovarii arising from a mature cystic teratoma (Figure $4(\mathrm{~A})$ ), and immunocytochemistry performed after the operation revealed that the tumor cells were positive for thyroglobulin (Figure $4(B))$. The patient made uneventful recovery, and was discharged on the post-operative third day. Pelvic USG revealed that the number of right ovarian follicles decreased (Figure 2(C)) and left ovarian tumor disappeared in her left adnexal lesion (Figure 2(D)).

The left ovarian mass having cystic and solid parts (Figure 5) was fixed in $4 \%$ buffered formalin, routinely processed, and embedded in paraffin for histological and immunohistochemical examinations. After which $3-4 \mu \mathrm{m}$-thick sections were stained with hematoxylin and eosin ( $\mathrm{H} \& \mathrm{E})$ for pathological diagnosis. In addition, immunohistochemistry using DAKO monoclonal antibodies, such as thyroglobulin (1:200 dilution, DAKO), thyroid transcription factor (TTF)-1 (1:200 dilution), inhibin (1:50 dilution) and calretinin (1:2000 dilution) was performed.

Histopathologically, the tumor consisted of normo- and macro-follicular thyroid tissue (Figure 6(A) and Figure 6(B)). Other components derived from germ layers except for thyroid tissue were also found. No atypical and/or immature cells were also recognized. Immunohistochemistry showed that glandular cells were positive for thyroglobulin (Figure 6(C)) and TTF-1 (Figure 6(D)), while they were negative for inhibing nor calretinin. Our final diagnosis was a pure stroma ovarii in the left ovary. The patient has no recurrent signs 7 months after the operation.

\section{Discussion}

In the present case, the imprint cytology and immunecytochemical and immunohistochemical examinations for thyroglobulin and TTF-1 were useful for the diagnosis of the pure struma ovarii, as reported by Wei et al. [15]. Although the detailed pathological information on her ovarian cystectomy, which was done before two years ago, could not be known and the possibility of the mature cystic teratoma exists. Our case was diagnosed as pure struma ovarii at the operation. Only a few cases concerning cytology of struma ovarii have been reported [13] [14]: their cytologic findings included the presence of typically colloid with mosaic pattern, follicles, follicular cells alone and/or sheets of follicular cells [14]. However, these findings are rare [14], as found in our case. On the other hand, immunocytochemistry was reported to be valuable tool for accurate diagnosis for the struma ovarii [13] [14].

Most cases of struma ovarii were asymptomatic, as is the present case [3]. When there is struma ovarii larger than normal thyroid, the patient rarely has hyperthyroidism: thyroid hyperfunction is noted in $5 \%-8 \%$ of cases [1]. Struma ovarii is defined as histologically characterized by the presence of thyroid-like 
glands at least $50 \%$, whereas pure struma ovarii has been reported in half number of all struma ovarii [1] [2]. Struma ovarii is predominantly found in women between the ages of 40 and 60 years [9]. The patient was 34 year-old and younger than predominant age distribution (Table 1).

Table 1. Sociodemographic and clinical characteristics of struma ovarii.

\begin{tabular}{|c|c|c|}
\hline & Struma ovarii & Present case \\
\hline Definition & $\begin{array}{l}\text {-A mature teratoma composed } \\
\text { either exclusively or predominantly } \\
\text { of thyroid tissue }\end{array}$ & $\begin{array}{l}\text {-Only thyroid tissue is present in the } \\
\text { lt. ovarian tumor }\end{array}$ \\
\hline Epidemiology & \multicolumn{2}{|c|}{-The most common type of monodermal teratoma } \\
\hline Age & $\begin{array}{l}\text {-Reproductive years } \\
\text { (mainly } 40 \text { - } 60 \text { years old) }\end{array}$ & -34 years old \\
\hline Clinical manifestations & $\begin{array}{l}\text {-Usually present with pain and/or a } \\
\text { pelvic mass } \\
\text {-Ascites (up to } 1 / 3 \text { of patients) } \\
\text {-Rarely hyperthyroidism }\end{array}$ & $\begin{array}{l}\text {-Secondary infertility } \\
\text {-Polycystic ovary syndrome } \\
\text { (rt ovary) } \\
\text {-No ascites and hyperthyroidism }\end{array}$ \\
\hline $\begin{array}{l}\text { Macroscopic findings } \\
\text { (Tumor size) }\end{array}$ & $\begin{array}{l}\text {-Usually unilateral and solid } \\
(<10 \mathrm{~cm})\end{array}$ & $\begin{array}{l}\text {-Lt. ovary occupied by cystic and } \\
\text { solid tumor tissues }(7 \mathrm{~cm})\end{array}$ \\
\hline Serum CA125 level & $\begin{array}{l}\text {-High level of CA125 is suggestive of } \\
\text { malignancy }\end{array}$ & $\begin{array}{l}\text {-Within normal limits } \\
(7.2 \mathrm{U} / \mathrm{ml})\end{array}$ \\
\hline Histopathology & $\begin{array}{l}\text {-Mature thyroid tissue is present } \\
\text { predominantly (over } 50 \% \text { ) in mature } \\
\text { ovarian teratoma }\end{array}$ & $\begin{array}{l}\text {-Thyroid tissue is present exclusively } \\
\text { in lt. ovarian cystic tumor with } \\
\text { papillary projection }\end{array}$ \\
\hline $\begin{array}{l}\text { Malignant } \\
\text { transformation }\end{array}$ & $\begin{array}{l}\text {-About } 5 \% \\
\text {-Mostly papillary carcinoma with } \\
\text { BRAF mutations and } R E T / P T C \\
\text { rearrangements }\end{array}$ & -None \\
\hline $\begin{array}{l}\text { Prognosis \& } \\
\text { follow-up time }\end{array}$ & $\begin{array}{l}\text {-Most cases of typical struma ovarii } \\
\text { are benign. } \\
\text {-The outcome of histologically and } \\
\text { biologically malignant thyroid type } \\
\text { tumors in struma is favourable }\end{array}$ & -Well, 7 months after the operation \\
\hline
\end{tabular}
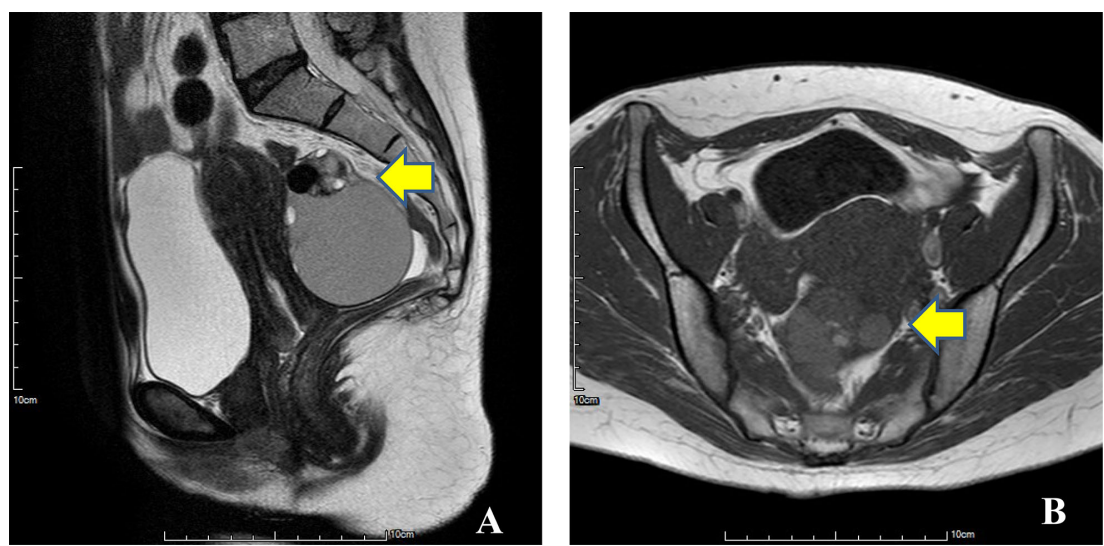

Figure 1. Pelvic MRI shows multiple small cysts with thick separations (arrow), some of them filled with colloidal material which show as low signal density in T2-weighted (A) and relative high (arrow) in T1-weighted (B). 


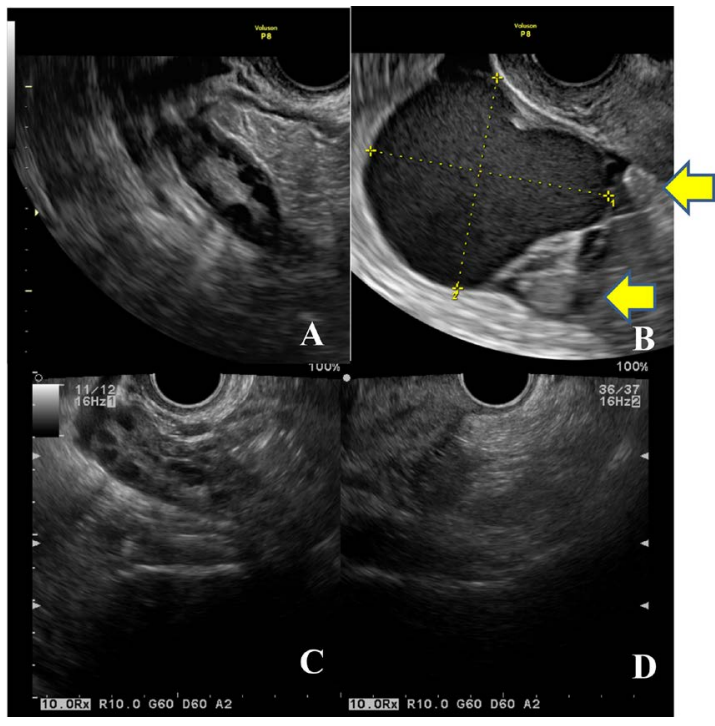

Figure 2. Pelvic ultrasongraphic images before and after surgery. Before surgery, right ovary showed polycystic ovary syndrome (A) and left ovary showed large cystic tumor with papillary protrusions (arrows) (B). After surgery, right ovary showed normal appearance (C) and the adnexal tumor disappeared (D).

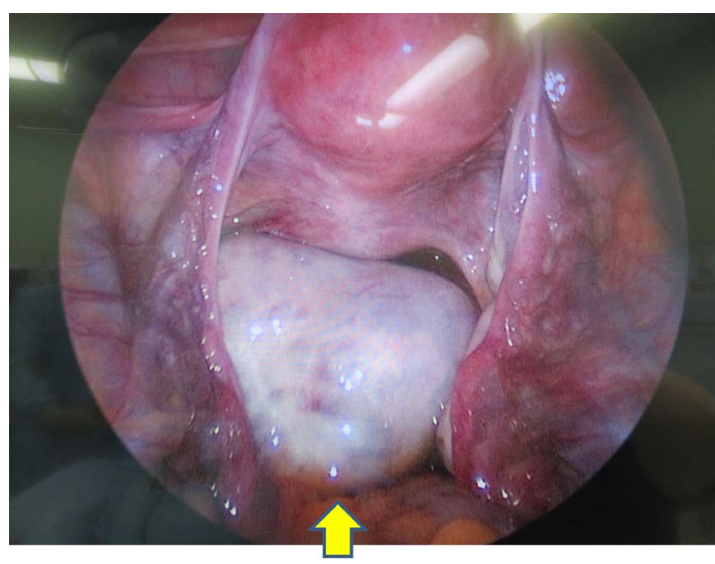

Figure 3. Laparoscopic findings of the left ovarian tumor (arrow).
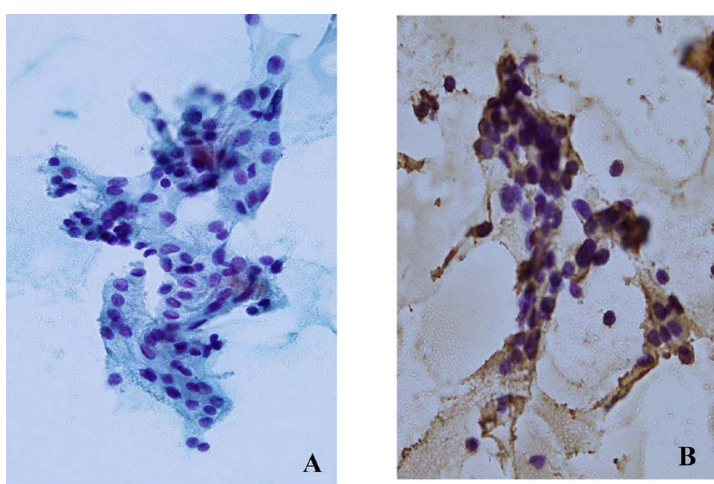

Figure 4. The imprint cytology on the left ovarian tumor. Glandular cells without atypia (A) are imunocytochmeicallypositive for thyroglobulin (B). (A) Papanicolaou stain (original magnification, $\times 100$ ) and (B) thyroglobulin immunohistochemistry (original magnification, $\times 100$ ). 


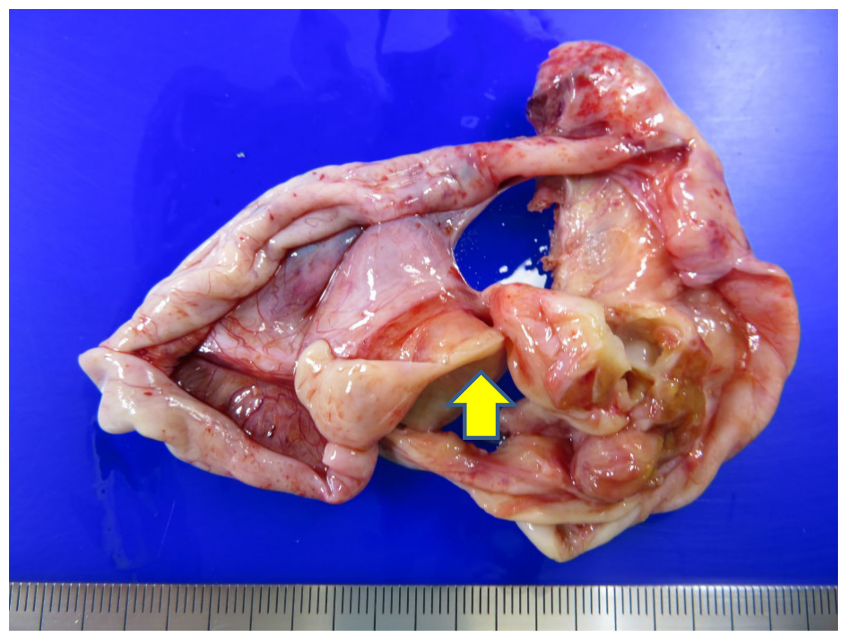

Figure 5. Macroscopic view of the left ovary. The tumor replaced the left ovary. The tumor consisted with solid (arrow) and cystic parts containing gelatinous and colloidal fluid.
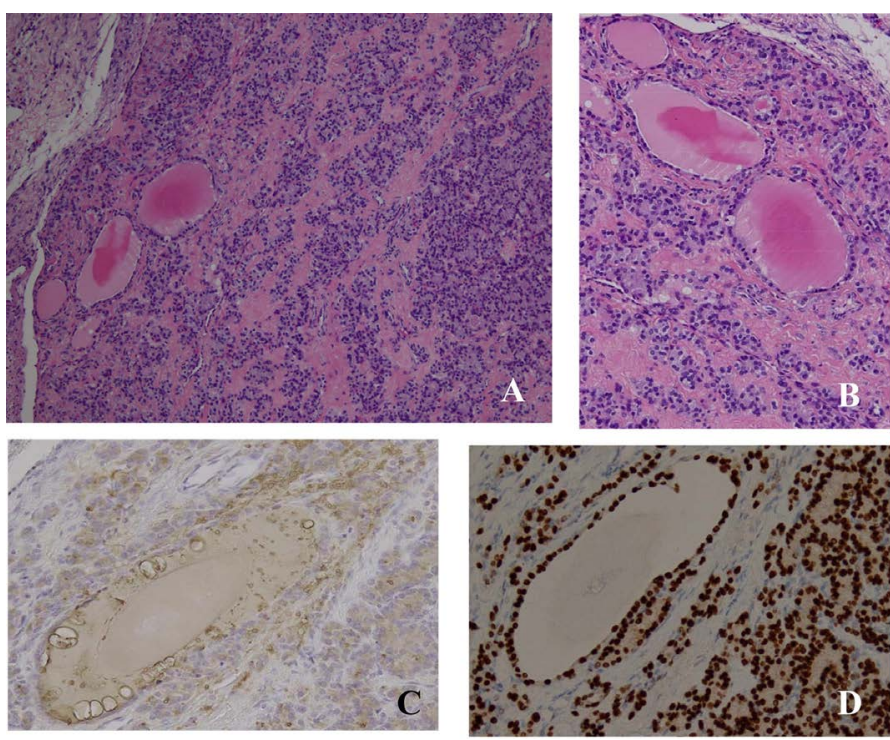

Figure 6. Histopathologyof the left ovarian tumor. Microscopically, the tumor is consisted of colloid-containing follicles with varying sizes without nuclear atypia $(\mathrm{A}, \times 20 ; \mathrm{B}, \times 40, \mathrm{H} \& \mathrm{E})$. Imminohistochemically, the tumor cell are positive for thyroglobulin $(\mathrm{C}, \times 100)$ and TTF-1 $(\mathrm{D}, \times 100)$.

Before operation, MRI findings are reported to be useful for the differential diagnosis for the struma ovarii [10] [11] [12]. MRI findings show multilocular cysts with solid components of variable signal density within the loculi. Signal intensity is slightly high on T1-weighted image and very low on T2-weighted image. These findings may suggest presence of hemorrhage or gelatinous (highly viscous) colloidal material of the content [10] [11] [12].

As described in previous reports, the key management of struma ovarii is surgical removal [1] [2] [4] [5]. Fertility-conserving surgery in most cases could be performed in the cases of their stated desire or potential for fertility. Laparos- 
copic removal of large ovarian cysts has been well-established and technically feasible for struma ovarii [16] [17]. As struma ovarii is often diagnosed post-operatively, there is concern that the removal of potentially malignant ovarian struma ovarii via laparoscopy may not determine the accurate stage, and increase the possible port site metastasis and spillage of tumor cells into the abdominal cavity. Therefore, we considered that taking out of the ovarian cystic tumor with struma ovarii without rupture must be important, and imprint cytology was useful for diagnosis struma ovarii.

\section{Conclusion}

A case of pure struma ovarii tumor diagnosed by cytology during a laparoscopic surgery was reported. The patient was a 34-year-old Japanese woman underwent a laparoscopic left oophorectomy under a preoperative diagnosis of endometriotic cyst or mature cystic teratoma in the left ovary. The content of the left ovarian cystic tumor was yellow gelatinous, suggesting a presence of mature cystic teratoma. The imprint cytology of the tumor showed benign glandular pattern, like as a struma ovarii. Histopathological findings led to the diagnosis of pure struma ovarii with a strong positive reaction for thyroglobulin and TTF-1. No other metastases or disseminated lesions were detected. The patient has no recurrent signs 7 months after her operation.

\section{Acknowledgements}

We thank the editor and reviewers for the constructive comments, which helped us to improve the manuscript. This case report was approved by the patient verbal consent.

\section{Conflicts of Interest}

The authors declare no conflicts of interest regarding the publication of this paper.

\section{Authors' Contributions}

\begin{tabular}{|c|c|c|c|c|c|c|c|c|}
\hline Authors' contributions & $\mathrm{KN}$ & MT & TI & SM & KK & SM & YY & TT \\
\hline Research concept and design & $\mathrm{y}$ & $\mathrm{n}$ & $\mathrm{n}$ & $\mathrm{n}$ & $\mathrm{n}$ & $\mathrm{n}$ & $\mathrm{n}$ & $\mathrm{n}$ \\
\hline Collection and/or assembly of data & $\mathrm{y}$ & $\mathrm{y}$ & $\mathrm{y}$ & $\mathrm{n}$ & $\mathrm{y}$ & $\mathrm{y}$ & $\mathrm{y}$ & $\mathrm{n}$ \\
\hline Data analysis and interpretation & $\mathrm{y}$ & $\mathrm{y}$ & $\mathrm{y}$ & $\mathrm{y}$ & $\mathrm{y}$ & $\mathrm{y}$ & $\mathrm{y}$ & $\mathrm{n}$ \\
\hline Writing the article & $\mathrm{y}$ & $\mathrm{n}$ & $\mathrm{n}$ & $\mathrm{n}$ & $\mathrm{n}$ & $\mathrm{n}$ & $\mathrm{n}$ & $\mathrm{n}$ \\
\hline Critical revision of the article & $\mathrm{y}$ & $\mathrm{n}$ & $\mathrm{n}$ & $\mathrm{n}$ & $\mathrm{n}$ & $\mathrm{n}$ & $\mathrm{n}$ & $\mathrm{y}$ \\
\hline Final approval of article & $\mathrm{y}$ & $\mathrm{y}$ & $\mathrm{y}$ & $\mathrm{y}$ & $\mathrm{y}$ & $\mathrm{y}$ & $\mathrm{y}$ & $\mathrm{y}$ \\
\hline
\end{tabular}

\section{References}

[1] Roth, L.M. and Talerman, A. (2007) The Enigma of Struma Ovarii. Pathology, 39, 
139-146. https://doi.org/10.1080/00313020601123979

[2] Yoo, S.C., Chang, K.H., Lyu, M.O., Chang, S.J., Ryu, H.S. and Kim, H.S. (2008) Clinical Characteristics of Struma Ovarii. Journal of Gynecologic Oncology, 19, 135-138. https://doi.org/10.3802/jgo.2008.19.2.135

[3] Prat, J., Cao, D., Carinelli, S.G., Nogales, F.F., Vang, R. and Zaloudek, C.J. (2014) Monodermal Tratomas and Somatic-Type Tumours Arising from a Dermoid Cyst. In: Kurman, R.J., Carcangiu M.L., Herrington, C.S., Young, R.H., Eds., WHO Classification of Tumours of Female Reproductive Organs, International Agency for Research on Cancer (IARC), WHO Press, Lyon, 63.

[4] Mancuso, A., Triolo, O., Leonardi, I. and De Vivo, A. (2001) Struma Ovarii: A Rare Benign Pathology Which May Erroneously Suggest Malignancy. Acta Obstetricia et Gynecologica Scandinavica, 80, 1075-1076. https://doi.org/10.1034/j.1600-0412.2001.801121.x

[5] Wee, J.Y., Li, X., Chern, B.S. and Chua, I.S. (2015) Struma Ovarii: Management and Follow-Up of a Rare Ovarian Tumour. Singapore Medical Journal, 56, 35-39. https://doi.org/10.11622/smedj.2015007

[6] Boutross-Tadross, O., Saleh, R. and Asa, S.L. (2007) Follicular Variant Papillary Thyroid Carcinoma Arising in Struma Ovarii. Endocrine Pathology, 18, 182-186. https://doi.org/10.1007/s12022-007-0022-8

[7] Schmidt, J., Derr, V., Heinrich, M.C., Crum, C.P., Fletcher, J.A., Corless, C.L. and Nose, V. (2007) BRAF in Papillary Thyroid Carcinoma of Ovary (Struma Ovarii). The American Journal of Surgical Pathology, 31, 1337-1343. https://doi.org/10.1097/PAS.0b013e31802f5404

[8] Devaney, K., Snyder, R., Norris, H.J. and Tavassoli, F.A. (1993) Proliferative and Histologically Malignant Struma Ovarii: A Clinicopathologic Study of 54 Cases. International Journal of Gynecological Pathology, 12, 333-343. https://doi.org/10.1097/00004347-199310000-00008

[9] Ayhan, A., Yanik, F., Tuncer, R., Tuncer, Z.S. and Ruacan, S. (1993) Struma Ovarii. International Journal of Gynecology \& Obstetrics, 42, 143-146. https://doi.org/10.1016/0020-7292(93)90628-A

[10] Fujiwara, S., Tsuyoshi, H., Nishimura, T., Takahashi, N. and Yoshida, Y. (2018) Precise Preoperative Diagnosis of Struma Ovarii with Pseudo-Meigs' Syndrome Mimicking Ovarian Cancer with the Combination of (131)I Scintigraphy and (18)F-FDG PET: Case Report and Review of the Literature. Journal of Ovarian Research, 11, 11. https://doi.org/10.1186/s13048-018-0383-2

[11] Ikeuchi, T., Koyama, T., Tamai, K., Fujimoto, K., Mikami, Y., Konishi, I. and Togashi, K. (2012) CT and MR Features of Struma Ovarii. Abdominal Radiology, 37, 904-910. https://doi.org/10.1007/s00261-011-9817-7

[12] Matsuki, M., Kaji, Y., Matsuo, M. and Kobashi, Y. (2000) Struma Ovarii: MRI Findings. The British Journal of Radiology, 73, 87-90. https://doi.org/10.1259/bjr.73.865.10721328

[13] Daneshbod, Y., Atefi, S., Daneshbod, K. and Ganjei-Azar, P. (2007) Cytologic Findings in Struma Ovarii. Diagnostic Cytopathology, 35, 612-614. https://doi.org/10.1002/dc.20696

[14] Daneshbod, Y., Daneshbod, K., Rasekhi, A.R., Mosayebi, Z., Negahban, S., Hodjati, S.R., Bedayat, G.R. and Ganjei-Azar, P. (2008) Cytologic Differentiation of Struma Ovarii from Other Ovarian Neoplasms. Acta Cytologica, 52, 72-76. https://doi.org/10.1159/000325437

[15] Wei, S., Baloch, Z.W. and Li Volsi, V.A. (2015) Pathology of Struma Ovarii: A Re- 
port of 96 Cases. Endocrine Pathology, 26, 342-348.

https://doi.org/10.1007/s12022-015-9396-1

[16] Ezon, I., Zilbert, N., Pinkney, L., Wei, J.J., Malik, R. and Nadler, E.P. (2007) A Large Struma Ovarii Tumor Removed via Laparoscopy in a 16-Year-Old Adolescent. Journal of Pediatric Surgery, 42, E19-E22.

https://doi.org/10.1016/j.jpedsurg.2007.05.003

[17] Nurliza Binti Md, N., Kusumoto, T., Inoue, S., Nakamura, K., Seki, N., Hongo, A., Kodama, J. and Hiramatsu, Y. (2013) Three Cases of Struma Ovarii Underwent Laparoscopic Surgery with Definite Preoperative Diagnosis. Acta Medica Okayama, 67, 191-195. 